\title{
Update on Programmed Death-1 and Programmed Death-Ligand 1 Inhibition in the Treatment of Advanced or Metastatic Non-Small Cell Lung Cancer
}

\author{
Marco A. J. lafolla and Rosalyn A. Juergens* \\ Department of Oncology, Juravinski Cancer Centre, McMaster University, Hamilton, ON, Canada
}

Purpose: Non-small-cell lung cancer (NSCLC) has a large worldwide prevalence with a high mortality rate. Chemotherapy has offered modest improvements in survival over the past two decades. Immune checkpoint modulation with programmed death-1 (PD-1) or programmed death-ligand 1 (PD-L1) inhibition has shown the promise of changing

OPEN ACCESS

Edited by:

Vera Hirsh,

McGill University, Canada

Reviewed by:

Timothy F. Burns,

University of Pittsburgh

Cancer Institute, USA

Nathalie Heuzé-Vourc'H,

CEPR INSERM U1100

and Université Francois Rabelais,

France

*Correspondence:

Rosalyn A. Juergens

juergensr@hhsc.ca

Specialty section:

This article was submitted

to Thoracic Oncology,

a section of the journal

Frontiers in Oncology

Received: 18 January 2017

Accepted: 23 March 2017

Published: 06 April 2017

Citation:

lafolla MAJ and Juergens RA (2017) Update on Programmed Death-1 and Programmed Death-Ligand 1

Inhibition in the Treatment of

Advanced or Metastatic Non-

Small Cell Lung Cancer.

Front. Oncol. 7:67.

doi: 10.3389/fonc.2017.00067 the future landscape of cancer therapy. This update reviews recent advances in the treatment of NSCLC with immune checkpoint modulation.

Methods: Publications and proceedings were identified from searching PubMed and proceedings from the annual meetings of the American Society of Clinical Oncology, European Society for Medical Oncology, and European Lung Cancer Conference.

Results: Atezolizumab, nivolumab, and pembrolizumab increase overall survival in second-line treatment of Stage III/IV squamous and non-squamous NSCLC when compared to docetaxel. Pembrolizumab increases progression-free survival in the first-line treatment of Stage IV NSCLC with 50\% PD-L1 expression when compared to platinum-based chemotherapy. Combination therapy with chemotherapy and cytotoxic T-lymphocyte-associated protein 4 (CTLA-4) inhibitors has shown promise in early trials.

Conclusion: Immune checkpoint modulation produces durable responses and overall survival benefits with less toxicity compared to conventional chemotherapy. Future investigations are combining PD-1/L1 inhibition with chemotherapy, targeted therapy, or other immuno-oncology agents in an effort to further improve efficacy.

Keywords: non-small-cell lung cancer, immuno-oncology, programmed death-1, programmed death-ligand 1 , CTLA-4

\section{INTRODUCTION}

More than 100 years of research in the field of cancer immunotherapy has produced several modalities capable of producing clinical response (1). Most notably, immune checkpoint modulation has shown the promise of changing the future landscape of cancer therapy through its durable clinical responses (2-4) and safety profiles of some agents that are either milder and/or more manageable compared to traditional anti-neoplastic therapies (5). Cytotoxic T-lymphocyte-associated protein 4 (CTLA-4), the first immune checkpoint receptor to be clinically targeted, is exclusively expressed on the surface of $\mathrm{CD}^{+}$and $\mathrm{CD} 8^{+} \mathrm{T}$ cells in lymphatic tissue and is involved in T-cell regulation, 
proliferation, and tolerance (6). The repertoire of immune modulation was expanded with the advent of programmed death-1 (PD-1) immune checkpoint inhibitor antibodies, which restores T-cell effector function and augments the host anti-tumor response by blocking the binding of either programmed deathligand 1 (PD-L1) and/or PD-L2 to PD-1 receptors (7).

Following the clinical success of treating melanoma with immune checkpoint modulation (8), trialists have expanded the application of checkpoint inhibitors to multiple tumor types, including lung cancer (9). Globally, 1.8 million new diagnoses of lung cancer occurred in 2012; with a mortality rate of nearly $90 \%$, lung cancer is the first and second cause of cancer mortality in men and women, respectively (10). Eighty-five percent of lung cancers are non-small-cell lung cancer (NSCLC), further divided into non-squamous (70\%) and squamous (30\%) histologic subtypes (11). Metastatic disease is present in $50 \%$ of new NSCLC diagnoses $(12,13)$, which harbors an untreated median overall survival (mOS) of 4.0 months (14) and a metastatic 5-year survival rate ranging from 2 to $9 \%$ (15). Although mortality has improved with the use of targeted drugs for driver mutations (16-20), few patients harbor these mutations and resistance to targeted treatment frequently occurs (21). Currently, NSCLC has numerous checkpoint inhibitors being evaluated for clinical efficacy (22). The possible treatment of NSCLC is being further enriched through the addition of other immune modulation targets and combination therapy. At present, the Food and Drug Administration has approved three immuno-oncology agents for the treatment of NSCLC: atezolizumab, nivolumab, and pembrolizumab in the relapsed, refractory setting as well as pembrolizumab for the firstline treatment of metastatic NSCLC with a tumor proportion score (TPS) $\geq 50 \%$. This update will offer guidance into the current application and pending developments for treatment NSCLC with immune modulating pharmacotherapy.

\section{METHODS}

Current studies investigating the use of immune checkpoint modulation in NSCLC were reviewed by searching PubMed (January 1, 2015 to December 30, 2016) using the following search terms: non-small-cell lung cancer and immune checkpoint modulation (or aliases). Any proceedings from the American Society of Clinical Oncology (ASCO) (2015-2016), European Society for Medical Oncology (ESMO) (2015-2016), and European Lung Cancer Conference (ELCC) (2015-2016) annual meetings involving both NSCLC and immune checkpoint modulation were reviewed. Table 1 summarizes the search results and each trial's pertinent characteristics.

\section{RESULTS}

\section{Third Line}

CheckMate 063 is a Phase 2, open-label, global, multicenter, single-arm trial investigating the use of nivolumab, a fully human immunoglobulin G4 (IgG4) monoclonal antibody that selectively inhibits the PD-1 receptor, dosed $3 \mathrm{mg} / \mathrm{kg}$ every 2 weeks $(n=117)$ in patients with either Stage IIIb/IV squamous NSCLC who have received prior platinum-doublet and one additional systemic treatment. Treatment with nivolumab continued until progressive disease $(\mathrm{PD})$ or an unacceptable treatment-related adverse event (TRAE), although treatment beyond PD was permitted as per protocol. The primary endpoint was overall response rate (ORR) by independent radiology review (per RECIST v1.1). The ORR was $14.5 \%$ (95\% CI 9-22). mOS was 8.2 months $(95 \% \mathrm{CI}$ 6.1-10.9), with 12-month OS and 18-month OS rates of $39 \%$ (95\% CI 30-48) and 27\% (95\% CI 19-35), respectively. TRAE of any Grade occurred in $75 \%$ of patients, Grade 3-4 TRAEs occurred in $17 \%$, TRAE lead to nivolumab discontinuation in $12 \%$, and death occurred in two patients secondary to nivolumab, although these patients had multiple comorbidities in the setting of PD $(23,24)$. These results are similar to those obtained from two smaller Japanese trials (25). To put this in historical perspective, a retrospective analysis looking at third-line treatment (58\% received cytotoxic chemotherapy, $42 \%$ EGFR received tyrosine kinase inhibitors) in patients who had not received any immunotherapy found a 6.5-month mOS, 3.4-month median progression-free survival (mPFS), and 8\% ORR (26).

\section{Second Line}

CheckMate 017 is a Phase 3, global, multicenter, open-label, 1:1 randomized trial comparing nivolumab $3 \mathrm{mg} / \mathrm{kg}$ every 2 weeks $(n=135)$ or docetaxel $75 \mathrm{mg} / \mathrm{m}^{2}$ every 3 weeks $(n=137)$ in patients with Stage IIIb/IV squamous NSCLC histology that recurred or progressed following prior platinum-doublet therapy. Treatment continued until PD or unacceptable toxicity, and treatment beyond PD was allowed. The primary endpoint was OS. Nivolumab had an mOS of 9.2 months (95\% CI 7.33-12.62) versus docetaxel with 6.0 months (95\% CI 5.29-7.39). The risk of death was $41 \%$ lower with nivolumab versus docetaxel [hazard ratio (HR) 0.59 , 95\% CI 0.44-0.79; $p<0.001]$. The ORR with nivolumab was 20 versus $9 \%$ with docetaxel. PD-L1 expression stratified to 1,5 , and $10 \%$ was not predictive of benefit. Nivolumab had less TRAEs compared to docetaxel: TRAEs of any grade were reported in 59 versus $87 \%$ of patients, respectively, and Grades 3-4 TRAEs were reported in 8 versus $56 \%$ of patients, respectively. Study discontinuation due to a TRAE was reported for $5 \%$ of nivolumab versus $10 \%$ of docetaxel patients. No treatment-related deaths occurred with nivolumab and two deaths occurred in patients receiving docetaxel that were determined to be treatment-related (27). This efficacy is similar to the single-arm CheckMate 063 results (23). OS was updated at the ASCO 2016 Annual Meeting: the 1- and 2-year OS for nivolumab was 42 and 23\%, respectively, in comparison to 24 and $8 \%$ for docetaxel (28).

CheckMate 057 is a Phase 3, global, multicenter, open-label, 1:1 randomized trial comparing nivolumab $3 \mathrm{mg} / \mathrm{kg}$ every 2 weeks $(n=292)$ to docetaxel $75 \mathrm{mg} / \mathrm{m}^{2}$ every 3 weeks $(n=290)$ in patients with Stage III/IV non-squamous NSCLC that recurred or progressed on platinum-doublet chemotherapy. Treatment continued until PD or discontinuation due to toxicity; treatment beyond PD was permitted per protocol. This study met its primary endpoint of OS, with nivolumab mOS 12.2 months versus docetaxel 9.4 months, yielding a $27 \%$ reduction in risk of death (HR 0.73; $p=0.002$ ) and improved ORR (19 versus $12 \%$; $p=0.02$ ). Using pre-defined PD-L1 expression levels of $\geq 1, \geq 5$, 
TABLE 1 | Summary of advanced or metastatic non-small-cell lung cancer immuno-oncology trials.

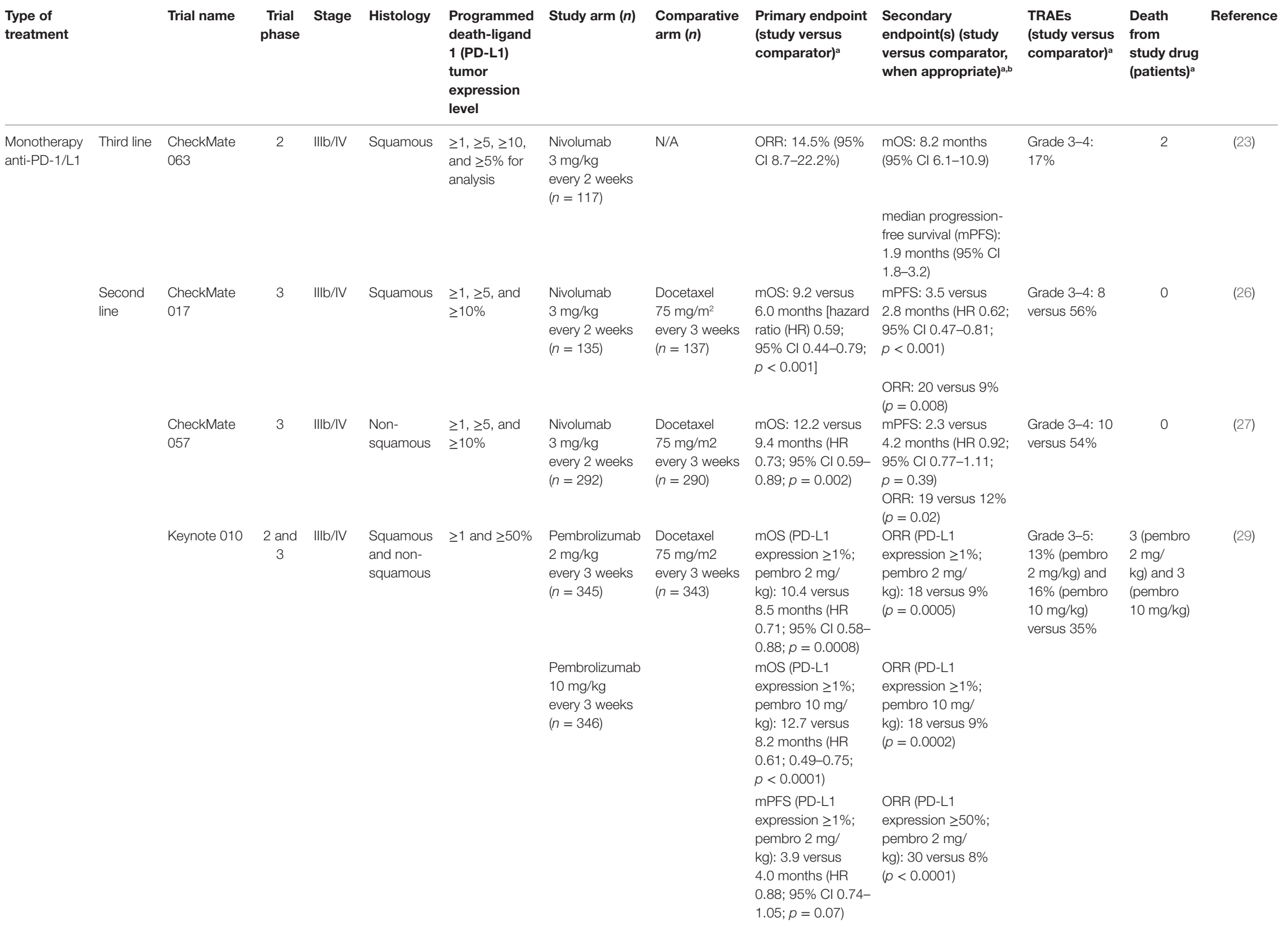


TABLE 1 | Continued

\begin{tabular}{|c|c|c|c|c|c|c|c|c|c|c|c|c|}
\hline $\begin{array}{l}\text { Type of } \\
\text { treatment }\end{array}$ & Trial name & $\begin{array}{c}\text { Trial } \\
\text { phase }\end{array}$ & Stage & Histology & $\begin{array}{l}\text { Programmed } \\
\text { death-ligand } \\
1 \text { (PD-L1) } \\
\text { tumor } \\
\text { expression } \\
\text { level }\end{array}$ & Study arm $(n)$ & $\begin{array}{l}\text { Comparative } \\
\operatorname{arm}(n)\end{array}$ & $\begin{array}{l}\text { Primary endpoint } \\
\text { (study versus } \\
\text { comparator) }^{\mathrm{a}}\end{array}$ & $\begin{array}{l}\text { Secondary } \\
\text { endpoint(s) (study } \\
\text { versus comparator, } \\
\text { when appropriate)a,b }\end{array}$ & $\begin{array}{l}\text { TRAEs } \\
\text { (study versus } \\
\text { comparator) }^{\mathrm{a}}\end{array}$ & $\begin{array}{l}\text { Death } \\
\text { from } \\
\text { study drug } \\
\text { (patients) }^{\mathrm{a}}\end{array}$ & Reference \\
\hline & & & & & & & & 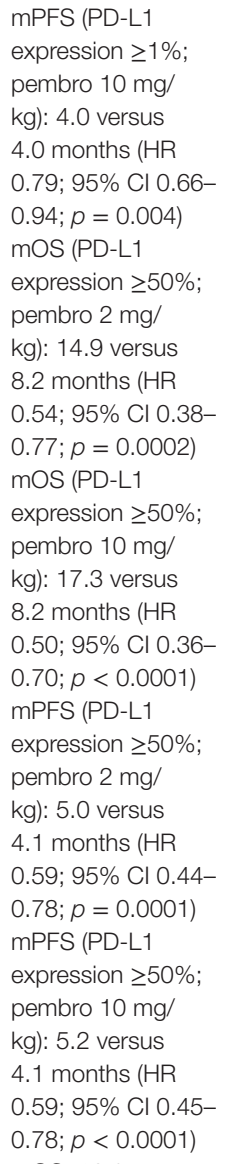 & $\begin{array}{l}\text { ORR (PD-L1 } \\
\text { expression } \geq 50 \% \text {; } \\
\text { pembro } 10 \mathrm{mg} / \\
\mathrm{kg}): 29 \% \text { vs } 8 \% \\
(p<0.0001)\end{array}$ & & & \\
\hline & OAK & 3 & Illb/IV & $\begin{array}{l}\text { Squamous } \\
\text { and non- } \\
\text { squamous }\end{array}$ & $\begin{array}{l}\text { TC/IC } 0=<1 \% \\
\text { TC/IC; TC/ } \\
\text { IC } 1=\geq 1 \% \\
\text { TC/IC; TC/ } \\
\text { IC } 2=\geq 5 \% \\
\text { TC/IC; TC/ } \\
\text { IC } 3=\geq 50 \% \\
\text { TC/ } \geq 10 \% \text { IC }\end{array}$ & $\begin{array}{l}\text { Atezolizumab } \\
1,200 \mathrm{mg} \\
(n=425) \text { every } \\
3 \text { weeks }\end{array}$ & $\begin{array}{l}\text { Docetaxel } \\
75 \mathrm{mg} / \mathrm{m}^{2} \\
\text { every } 3 \text { weeks } \\
(n=425)\end{array}$ & $\begin{array}{l}\text { mOS: } 13.8 \text { versus } \\
9.6 \text { months (HR } \\
0.73 ; 95 \% \mathrm{Cl} \mathrm{0.62-} \\
0.87 ; p=0.0003)\end{array}$ & $\begin{array}{l}\text { mPFS: } 4.0 \text { versus } \\
2.8 \text { months (HR 0.95; } \\
95 \% \mathrm{Cl} 0.82-1.10 \\
p=0.493)\end{array}$ & $\begin{array}{l}\text { Grade 3-4: } 15 \\
\text { versus } 43 \%\end{array}$ & 0 & (31) \\
\hline
\end{tabular}


TABLE 1 | Continued

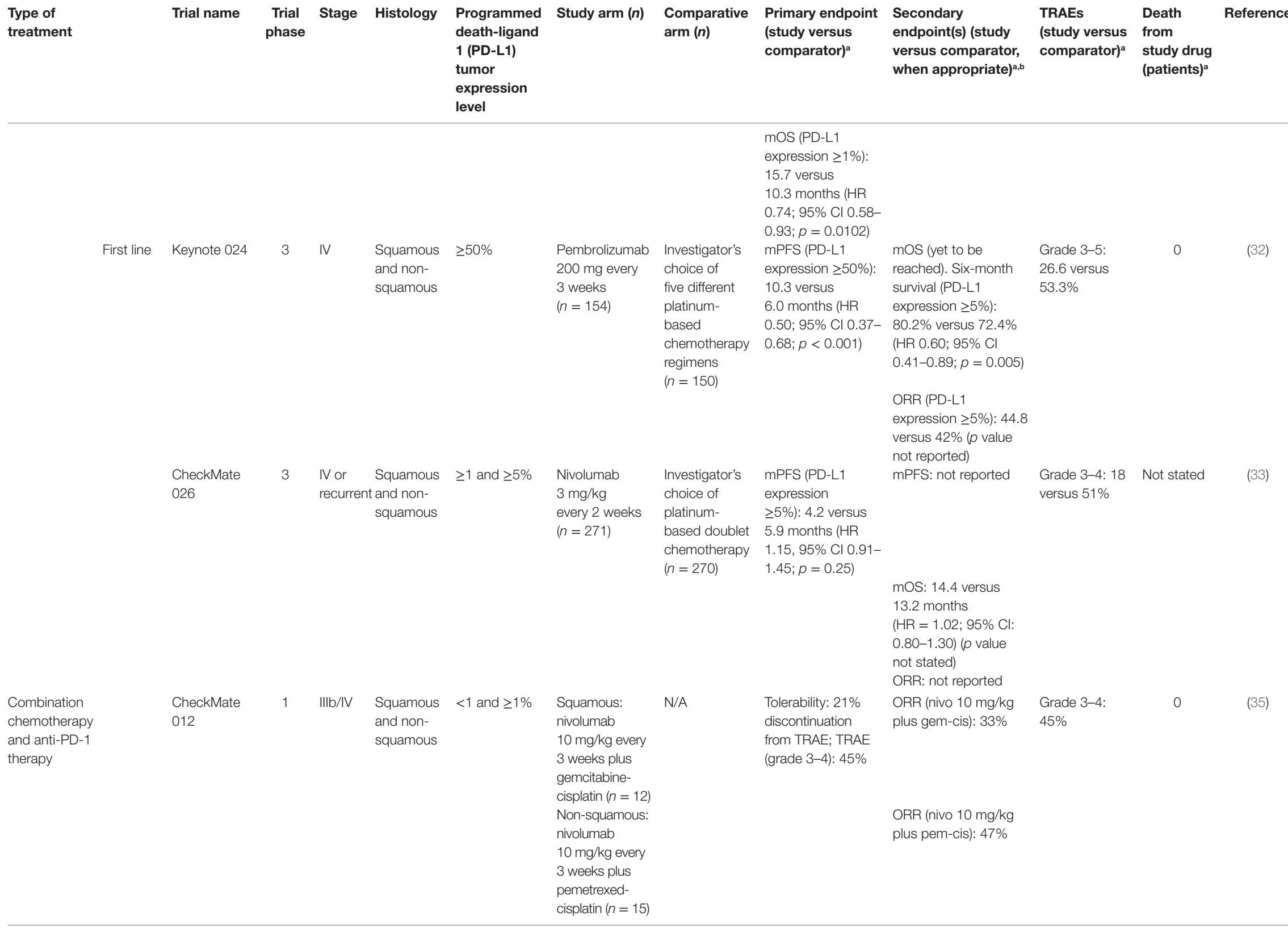


TABLE 1 | Continued

\begin{tabular}{|c|c|c|c|c|c|c|c|c|c|c|c|c|}
\hline $\begin{array}{l}\text { Type of } \\
\text { treatment }\end{array}$ & Trial name & $\begin{array}{c}\text { Trial } \\
\text { phase }\end{array}$ & Stage & Histology & $\begin{array}{l}\text { Programmed } \\
\text { death-ligand } \\
1 \text { (PD-L1) } \\
\text { tumor } \\
\text { expression } \\
\text { level }\end{array}$ & Study arm $(n)$ & $\begin{array}{l}\text { Comparative } \\
\operatorname{arm}(n)\end{array}$ & $\begin{array}{l}\text { Primary endpoint } \\
\text { (study versus } \\
\text { comparator) }^{\mathrm{a}}\end{array}$ & $\begin{array}{l}\text { Secondary } \\
\text { endpoint(s) (study } \\
\text { versus comparator, } \\
\text { when appropriate), }\end{array}$ & $\begin{array}{l}\text { TRAEs } \\
\text { (study versus } \text { comparator) }\end{array}$ & $\begin{array}{l}\text { Death } \\
\text { from } \\
\text { study drug } \\
\text { (patients) }^{\mathrm{a}}\end{array}$ & Reference \\
\hline & & & & & & $\begin{array}{l}\text { All histologies: } \\
\text { nivolumab } 5 \\
\text { or } 10 \mathrm{mg} / \mathrm{kg} \\
\text { every } 3 \text { weeks } \\
\text { plus paclitaxel- } \\
\text { carboplatin } \\
\text { ( } n=14 \text { and } \\
n=15 \\
\text { respectively) }\end{array}$ & & & $\begin{array}{l}\text { ORR (nivo } 10 \mathrm{mg} / \mathrm{kg} \\
\text { plus pacli-carbo): } 47 \%\end{array}$ & & & \\
\hline & & & & & & & & (5) & $\begin{array}{l}\text { ORR (nivo } 5 \mathrm{mg} / \mathrm{kg} \\
\text { plus pacli-carbo): } 43 \% \\
\text { progression-free } \\
\text { survival (PFS) } \\
\text { ( } 24 \text { weeks; nivo } \\
10 \mathrm{mg} / \mathrm{kg} \text { plus gem- } \\
\text { cis): } 51 \% \\
\text { PFS ( } 24 \text { weeks; nivo } \\
10 \text { mg/kg plus pem- } \\
\text { cis): } 71 \% \\
\text { PFS ( } 24 \text { weeks; nivo } \\
10 \text { mg/kg plus pacli- } \\
\text { carbo): } 38 \% \\
\text { PFS ( } 24 \text { weeks; nivo } \\
5 \text { mg/kg plus pacli- } \\
\text { carbo): } 51 \%\end{array}$ & & & \\
\hline & Keynote 021 & $\begin{array}{c}1 \text { and } \\
2\end{array}$ & Illb/IV & $\begin{array}{l}\text { Non- } \\
\text { squamous }\end{array}$ & $<1$ and $\geq 1 \%$ & $\begin{array}{l}\text { Pembrolizumab } \\
200 \text { mg every } \\
3 \text { weeks plus } \\
\text { pemetrexed- } \\
\text { carboplatin } \\
(n=60)\end{array}$ & $\begin{array}{l}\text { Pemetrexed- } \\
\text { carboplatin } \\
(n=63)\end{array}$ & $\begin{array}{l}\text { ORR: } 55 \text { versus } \\
29 \%(95 \% \\
\text { Cl 9-42\%; } \\
p=0.0016)\end{array}$ & $\begin{array}{l}\text { mPFS: } 13.0 \text { versus } \\
8.9 \text { months (HR } 0.53 \\
95 \% \mathrm{Cl} 0.31-0.91 \\
p=0.010 \text { ) }\end{array}$ & $\begin{array}{l}\text { Grade 3-5: } 39 \\
\text { versus 26\% }\end{array}$ & 1 & (36) \\
\hline & & & & & & & & & $\begin{array}{l}\text { OS (12 months): } 75 \\
\text { versus } 72 \% \\
\text { ORR (<1versus } \geq 1 \% \\
\text { in pembro arm): } 57 \\
\text { versus } 54 \% \\
\text { ORR (PD-L1 } 1-49 \% \text { in } \\
\text { pembro arm): } 26 \% \\
\text { ORR (PD-L1 } \geq 50 \% \text { in } \\
\text { pembro arm): } 80 \%\end{array}$ & & & \\
\hline
\end{tabular}


TABLE 1 | Continued

\begin{tabular}{|c|c|c|c|c|c|c|c|c|c|c|c|c|}
\hline $\begin{array}{l}\text { Type of } \\
\text { treatment }\end{array}$ & Trial name & $\begin{array}{l}\text { Trial } \\
\text { phase }\end{array}$ & Stage & Histology & $\begin{array}{l}\text { Programmed } \\
\text { death-ligand } \\
1 \text { (PD-L1) } \\
\text { tumor } \\
\text { expression } \\
\text { level }\end{array}$ & Study arm $(n)$ & $\begin{array}{l}\text { Comparative } \\
\operatorname{arm}(n)\end{array}$ & $\begin{array}{l}\text { Primary endpoint } \\
\text { (study versus }^{\text {comparator) }^{\mathrm{a}}}\end{array}$ & $\begin{array}{l}\text { Secondary } \\
\text { endpoint(s) (study } \\
\text { versus comparator, } \\
\text { when appropriate) }{ }^{\mathrm{a}, \mathrm{b}}\end{array}$ & $\begin{array}{l}\text { TRAEs } \\
\text { (study versus } \\
\text { comparator) }\end{array}$ & $\begin{array}{l}\text { Death } \\
\text { from } \\
\text { study drug } \\
\text { (patients) }^{\mathrm{a}}\end{array}$ & Reference \\
\hline \multirow[t]{5}{*}{$\begin{array}{l}\text { Combination } \\
\text { anti-PD-1/L1 } \\
\text { therapy and } \\
\text { anti-CTLA-4 } \\
\text { therapy }\end{array}$} & Keynote 021 & $\begin{array}{c}1 \text { and } \\
2\end{array}$ & IIIb/IV & $\begin{array}{l}\text { Non- } \\
\text { squamous }\end{array}$ & $<1$ and $\geq 1 \%$ & $\begin{array}{l}\text { Maximum dose: } \\
\text { Pembrolizumab } \\
10 \mathrm{mg} / \mathrm{kg} \text { every } \\
3 \text { weeks plus } \\
\text { ipilimumab } 1 \text { or } \\
3 \mathrm{mg} / \mathrm{kg} \text { every } \\
3 \text { weeks (only } \\
\text { four cycles) } \\
\text { Final dose } \\
\text { selected: } \\
\text { pembrolizumab } \\
2 \text { mg/kg and } \\
\text { ipilimumab } \\
1 \text { mg } / \mathrm{kg}\end{array}$ & N/A & $\begin{array}{l}\text { TRAE (all grades): } \\
10 \text { patients (66.7\%) }\end{array}$ & None defined & $\begin{array}{l}\text { All grade: } \\
10 \text { patients } \\
\text { (66.7\%) }\end{array}$ & 0 & (37) \\
\hline & $\begin{array}{l}\text { CheckMate } \\
012\end{array}$ & 1 & IIIb/IV & $\begin{array}{l}\text { Squamous } \\
\text { and non- } \\
\text { squamous }\end{array}$ & $<1$ and $\geq 1 \%$ & $\begin{array}{l}\text { Nivolumab } \\
1 \mathrm{mg} / \mathrm{kg} \text { every } \\
2 \text { weeks plus } \\
\text { ipilimumab } \\
1 \mathrm{mg} / \mathrm{kg} \text { every } \\
6 \text { weeks (data } \\
\text { not reported in } \\
\text { publication) }\end{array}$ & N/A & $\begin{array}{l}\text { TRAE (grade 3-4; } \\
\text { ipi every } 6 \text { weeks): } \\
33 \%\end{array}$ & $\begin{array}{l}\text { ORR (ipi every } \\
6 \text { weeks): 38\% (95\% } \\
\text { Cl 23-55) }\end{array}$ & $\begin{array}{l}\text { TRAE (grade } \\
\text { 3-4; ipi every } \\
6 \text { weeks): } 33 \%\end{array}$ & 0 & (39) \\
\hline & & & & & & $\begin{array}{l}\text { Nivolumab } \\
3 \mathrm{mg} / \mathrm{kg} \text { every } \\
2 \text { weeks plus } \\
\text { ipilimumab } \\
1 \mathrm{mg} / \mathrm{kg} \text { every } \\
12 \text { weeks } \\
(n=38)\end{array}$ & & $\begin{array}{l}\text { TRAE (grade } 3-4 \text {; } \\
\text { ipi every } 12 \text { weeks): } \\
37 \%\end{array}$ & $\begin{array}{l}\text { ORR (ipi every } \\
12 \text { weeks): } 47 \% \text { (95\% } \\
\text { Cl 31-64) }\end{array}$ & $\begin{array}{l}\text { TRAE (grade } \\
3-4 \text {; ipi every } \\
12 \text { weeks): } \\
37 \%\end{array}$ & & \\
\hline & & & & & & $\begin{array}{l}\text { Nivolumab } \\
3 \mathrm{mg} / \mathrm{kg} \text { every } \\
2 \text { weeks plus } \\
\text { ipilimumab } \\
1 \mathrm{mg} / \mathrm{kg} \\
\text { every } 6 \text { weeks } \\
(n=39)\end{array}$ & & & $\begin{array}{l}\text { PFS ( } 24 \text { weeks; ipi } \\
\text { every } 6 \text { weeks): 65\% } \\
\text { (95\% Cl 42-81) }\end{array}$ & & & \\
\hline & & & & & & & & & $\begin{array}{l}\text { PFS (24 weeks; ipi } \\
\text { every } 12 \text { weeks): 80\% } \\
\text { (95\% Cl 55-92) }\end{array}$ & & & \\
\hline
\end{tabular}


and $\geq 10 \%$ from archival tumors, nivolumab showed improved efficacy across all endpoints. PD-L1 expression predicted the benefit of nivolumab, even at the lowest expression level of $1 \%$. mOS approximately doubled with nivolumab versus docetaxel across PD-L1 expression levels; conversely, survival was equivocal with negative PD-L1 expression. Grades 3-4 TRAEs occurred in 10 and $54 \%$ of nivolumab and docetaxel patients, respectively. There were no nivolumab-related deaths, whereas docetaxel led to one death. Subsequent systemic therapy was given to 42.1 and $49.7 \%$ of nivolumab and docetaxel patients, respectively (29). Investigators at the ASCO 2016 Annual Meeting presented an update to the 1 - and 2-year OS for nivolumab noting 51 and 29\%, respectively, in comparison to 39 and $16 \%$ for docetaxel (28).

Keynote 010 is Phase 2/3, global, multicenter, open-label, randomized, controlled study to evaluate the safety and efficacy of pembrolizumab, a humanized monoclonal IgG4 antibody that selectively inhibits the PD-1 receptor. Patients with NSCLC and tumor cell PD-L1 expression $\geq 1 \%$ who progressed after platinum-doublet chemotherapy were randomized 1:1:1 to receive pembrolizumab $2 \mathrm{mg} / \mathrm{kg}(n=345)$, pembrolizumab $10 \mathrm{mg} / \mathrm{kg}$ $(n=346)$, or docetaxel $75 \mathrm{mg} / \mathrm{m}^{2}(n=343)$ every 3 weeks; no crossover was allowed. Treatment was continued for 24 months, or until PD or discontinuation due to toxicity; treatment beyond PD was allowed. The primary endpoints were OS and progression-free survival (PFS) (by independent radiology review as per RECIST v1.1) in both all patients and those with PD-L1 expression $\geq 50 \%$ of tumor cells (TCs) from either archival or new biopsies. Compared to docetaxel, risk of death was decreased with both pembrolizumab $2 \mathrm{mg} / \mathrm{kg}$ (HR $0.71,95 \%$ CI $0.58-0.88$; $p=0.0008$ ) and pembrolizumab $10 \mathrm{mg} / \mathrm{kg}$ (HR 0.61, 0.49-0.75; $p<0.0001)$. Patients with PD-L1 expression $\geq 50 \%$ had better mOS with pembrolizumab $2 \mathrm{mg} / \mathrm{kg}$ (14.9 versus 8.2 months; HR $0.54,95 \%$ CI $0.38-0.77 ; p=0.0002$ ) and pembrolizumab $10 \mathrm{mg} / \mathrm{kg}$ (17.3 versus 8.2 months; HR 0.50 , 95\% CI $0.36-0.70$; $p<0.0001$ ) versus docetaxel. Grades 3-5 TRAEs were less common with pembrolizumab versus docetaxel: 13,16 , and $35 \%$ for those treated with pembrolizumab $2 \mathrm{mg} / \mathrm{kg}$, pembrolizumab $10 \mathrm{mg} / \mathrm{kg}$, and docetaxel, respectively (30). Investigators at the ASCO 2016 Annual Meeting presented an update on the patients with 1-49\% PD-L1 expression: OS was longer for both pembrolizumab $2 \mathrm{mg} / \mathrm{kg}$ (9.4 months) versus docetaxel (8.6 months) (HR 0.79, 95\% CI $0.61-1.04)$ and pembrolizumab $10 \mathrm{mg} / \mathrm{kg}$ (10.8 months) versus docetaxel (8.6 months) (HR 0.71, 0.53-0.94) (31).

The OAK study is a Phase 3, global, multicenter, open-label, randomized, controlled study to evaluate the efficacy and safety of atezolizumab, a humanized IgG1-kappa monoclonal antibody that binds PD-L1 and inhibits PD-L1/PD-1 and PD-L1/B7.1 interactions (32). Patients with Stage IIIb/IV or recurrent nonsquamous NSCLC following failure of platinum-based treatment were randomized 1:1 to receive either fixed dose atezolizumab $1,200 \mathrm{mg}(n=425)$ or docetaxel $75 \mathrm{mg} / \mathrm{m}^{2}(n=425)$ every 3 weeks; no crossover was allowed. Treatment continued until disease progression or unacceptable toxicity occurred; treatment beyond PD was allowed. The study had co-primary endpoints of OS in the full study population, in addition to OS in patients with PD-L1 expression $\geq 1 \%$ of TCs or tumor-infiltrating immune cells (IC) by the Ventana SP142 assay. mOS was significantly longer 
for atezolizumab versus docetaxel (13.8 versus 9.6 months, stratified HR 0.73, 95\% CI 0.62-0.87; $p=0.0003)$, and had 12- and 18 -month OS of 55 versus $41 \%$ and 40 versus $27 \%$, respectively. OS was significant regardless of presence of PD-L1 expression: 55\% of patients had PD-L1 expression $\geq 1 \%$ and had OS of 15.7 months versus docetaxel 10.3 months (stratified HR 0.74, 95\% CI $0.58-$ $0.93 ; p=0.0102) ; 45 \%$ of patients had no TC or IC with PD-L1 expression with a respective OS of 12.6 months versus docetaxel 8.9 months (HR 0.75, 95\% CI 0.59-0.96; $p=0.0215$ ); and $16 \%$ of patients had high TC $(\geq 50 \%)$ or IC ( $\geq 10 \%)$ PD-L1 expression and had OS of 20.5 months versus docetaxel 8.9 months (HR 0.41, 95\% CI 0.27-0.64; $p<0.0001$ ). Further, OS was also significant regardless of NSCLC histology: non-squamous NSCLC had OS of 15.6 months versus docetaxel 11.2 months (HR 0.73, 95\% CI 0.60-0.89; $p=0.0015$ ); squamous NSCLC had OS of 8.9 months versus docetaxel 7.7 months (HR 0.73, 95\% CI $0.54-0.98 ; p=0.0383$ ). Five percent of the atezolizumab group went on to receive subsequent immunotherapy versus $17 \%$ in the docetaxel group. Atezolizumab was well tolerated: only 15\% of patients treated with atezolizumab had Grades 3-4 adverse events compared to $43 \%$ of the patients treated with docetaxel (33).

\section{First Line}

Keynote 024 is Phase 3, global, multicenter, open-label, 1:1 randomized trial comparing fixed dose pembrolizumab $200 \mathrm{mg}$ every 3 weeks $(n=154)$ to the investigator's choice of five different platinum-based chemotherapy regimens $(n=150)$ in patients with both squamous and non-squamous Stage IV NSCLC who have not received prior systemic therapy for their metastatic disease and have PD-L1 expression on $\geq 50 \%$ of TCs. Treatment with pembrolizumab and platinum-based chemotherapy continued for a total of 35 cycles ( $~ 2$ years) and 4-6 cycles, respectively, or until the patient had radiologic disease progression or unacceptable toxicity. Pemetrexed maintenance was allowed for patients with non-squamous histology. Crossover from chemotherapy to pembrolizumab was allowed if PD occurred. The primary end point was PFS (by independent radiology review as per RECIST v1.1). mPFS was longer for pembrolizumab versus chemotherapy (10.3 versus 6.0 months) and disease progression or death was significantly better for pembrolizumab ( $\mathrm{HR}$ 0.50, 95\% CI $0.37-0.68$; $p<0.001)$. mOS has yet to be reached; however, the 6-month OS for pembrolizumab versus chemotherapy was 80.2 and $72.4 \%$, respectively (HR $0.60,95 \%$ CI $0.41-0.89 ; p=0.005$ ). Pembrolizumab had fewer TRAEs of any grade compared to chemotherapy (73.4 versus $90.0 \%$ ), less grade 3-5 TRAEs (26.6 versus $53.3 \%$ ), and although had higher rates of immune-TRAEs (29.2 versus $4.7 \%$ ) most were grade $1-2$ severities and did not lead to any deaths. The second interim analysis by the data and safety monitoring committee determined that the benefit of pembrolizumab was large enough to warrant stopping the trial and offer the chemotherapy group pembrolizumab (34).

CheckMate 026 is a Phase 3, global, multicenter, open-label, 1:1 randomized controlled trial comparing nivolumab $3 \mathrm{mg} / \mathrm{kg}$ every 2 weeks ( $n=271)$ to the investigator's choice of platinumbased doublet chemotherapy $(n=270)$ in patients with Stage IV or recurrent squamous and non-squamous NSCLC who have not received previous systemic therapy for their disease and have PD-L1 expression on $\geq 1 \%$ of TCs. Nivolumab continued until disease progression or unacceptable toxicity. Treatment beyond progression was allowed. Platinum-doublet chemotherapy was given for up to six cycles and pemetrexed maintenance was allowed for non-squamous patients. Crossover from chemotherapy to nivolumab was allowed if PD occurred. The primary end point was PFS (by independent radiology review as per RECIST v1.1) in patients with PD-L1 expression $\geq 5 \%$. Nivolumab did not improve mPFS compared to platinum-doublet among patients with PD-L1 expression $\geq 5 \%$ : 4.2 and 5.9 months, respectively (HR 1.15, 95\% CI 0.91-1.45; $p=0.25$ ). Surprisingly, in contrast to the Keynote 024 results, the PFS was not superior in the $\geq 50 \%$ PD-L1 cohort (PFS HR 1.07) in the subgroup analysis. The OS for the nivolumab and chemotherapy groups were similar with an mOS of 14.4 and 13.2 months, respectively ( $\mathrm{HR}=1.02,95 \%$ CI $0.80-1.30)$. Nivolumab had less TRAEs of any grade and grade 3-4 (71 and 18\%), respectively, when compared to platinumdoublet (92 and 51\%) (35). Further knowledge on the use of firstline nivolumab will be forthcoming from the ongoing CheckMate 227 trial where the 1\% PD-L1 positive arm includes patients randomized to combined immunotherapy with nivolumab and ipilimumab versus nivolumab alone versus chemotherapy in the first-line setting.

\section{Combinations of Immunotherapy and Chemotherapy}

CheckMate 012 is a multi-cohort phase I clinical trial evaluating nivolumab as a single agent or in combination with chemotherapy, targeted therapy, or ipilimumab (a recombinant human IgG1 immunoglobulin that inhibits the CTLA-4 receptor). The data have been published from the platinum-doublet combinations (36). Three chemotherapy backbones were evaluated in 56 patients: pemetrexed/cisplatin, gemcitabine/cisplatin, and paclitaxel/carboplatin. All three backbones were paired with nivolumab $10 \mathrm{mg} / \mathrm{kg}$. An additional cohort of paclitaxel/carboplatin was accrued that was combined with nivolumab $5 \mathrm{mg} / \mathrm{kg}$. Maintenance chemotherapy was not allowed but patients continued on maintenance of nivolumab until progression. The primary objective, ORR, was 47,33 , and $47 \%$ for the pemetrexed, gemcitabine and paclitaxel platinum combinations with the $10 \mathrm{mg} / \mathrm{kg}$ nivolumab dose, respectively; ORR for paclitaxel/carboplatin combination with $5 \mathrm{mg} / \mathrm{kg}$ nivolumab was $43 \%$. Responses were seen irrespective of presence or absence of PD-L1 expression on the tumor. Two-year OS rates were 33,25 , and $27 \%$, for the pemetrexed, gemcitabine and paclitaxel platinum combinations with the $10 \mathrm{mg} / \mathrm{kg}$ nivolumab dose, respectively. The 2-year OS rate for the paclitaxel/carboplatin combination with $5 \mathrm{mg} / \mathrm{kg}$ nivolumab was $62 \%$. These objective response and 2 -year survival rates for the nivolumab combinations were numerically increased over what we would have expected historically from platinum doublet. No dose-limiting toxicities occurred during the first two cycles of treatment. Forty-five percent of patients reported Grade 3-4 TRAEs; $21 \%$ of patients discontinued all study therapy as a result of TRAEs. 
Keynote 021 is a multi-cohort Phase $1 / 2$ randomized trial investigating the safety, tolerability, and efficacy of pembrolizumab in combination with platinum doublets, targeted therapy, and ipilimumab. The data were recently published from the randomized phase 2 cohort $G$ which compared pemetrexed and carboplatin followed by pemetrexed maintenance with or without a maximum of 2 years of pembrolizumab in 123 patients. Patients have Stage IIIb/IV non-squamous NSCLC and were stratified according to their PD-L1 TPS $<1$ versus $\geq 1 \%$. Crossover from the chemotherapy group to the pembrolizumab group was permitted in the event of PD. The primary endpoint was ORR (by independent radiology review as per RECIST v1.1). Pembrolizumab combined with chemotherapy has a superior ORR versus chemotherapy alone (55 versus $29 \%$, 95\% CI 9-42\%; $p=0.0016)$. Subgroup analysis of PD-L1 stratification $<1 \%$ versus $\geq 1 \%$ showed similar ORR for the pembrolizumab group (57 versus 54\%, respectively) while the chemotherapy alone group showed a difference in ORR (13 versus $38 \%$, respectively). Further stratification of PD-L1 to $1-49 \%$ and $\geq 50 \%$ had an ORR of 26 and $80 \%$, respectively, for the pembrolizumab with chemotherapy group, versus 39 and 35\%, respectively, for the chemotherapy alone group. Pembrolizumab with chemotherapy was able to achieve a superior mPFS versus chemotherapy alone (13.0 versus 8.9 months, HR 0.53 , 95\% CI $0.31-0.91$; $p=0.0102)$. mOS has not yet been met, and the 12-month OS has been $75 \%$ for those with pembrolizumab and chemotherapy versus $72 \%$ for chemotherapy alone. Grade 3-5 TRAEs were similar between groups $39 \%$ in the pembrolizumab plus chemotherapy group versus $26 \%$ in the chemotherapy alone group), with similar treatment discontinuation rates (10\% for the pembrolizumab arm compared to $13 \%$ for the chemotherapy only arm) and treatment-related deaths (one death in the pembrolizumab group secondary to sepsis, and two deaths in the chemotherapy alone group due to sepsis and pancytopenia) (37).

\section{Immunotherapy Doublets}

Based on the success of dual immunotherapy combinations in melanoma, PD-1 inhibitors have been combined with the CTLA-4 inhibitor, ipilimumab. Cohort $\mathrm{C}$ from the Keynote 021 trial described above was presented at the ASCO Annual Meeting in 2015 (38). This cohort was a dose finding and safety study. The initial doses of pembrolizumab were $10 \mathrm{mg} / \mathrm{kg}$ and doses of 1 or $3 \mathrm{mg} / \mathrm{kg}$ of ipilimumab were planned. There were no safety signals at the $10 \mathrm{mg} / \mathrm{kg}$ dose of pembrolizumab with either dose of ipilimumab in the six patients treated, but, based on the emerging results from the CheckMate 012 trial, the final dose selected for further dose expansion was pembrolizumab $2 \mathrm{mg} / \mathrm{kg}$ and ipilimumab $1 \mathrm{mg} / \mathrm{kg}$. Results were presented for the 15 patients treated at all dose levels. The ORR was $39 \%$ and the disease control rate was $83 \%$. Immune TRAEs were identified in $33 \%$ of patients, half of whom had Grade 3 events (adrenal insufficiency and skin eruptions). This combination is being explored further in a randomized two cohort of Keynote 021 (cohort H).

The CheckMate 012 trial had several arms assessing the optimal dosing of nivolumab and ipilimumab in chemotherapynaïve patients with NSCLC. Initial dose combinations with higher doses of ipilimumab (3 mg/kg) given every 3 weeks, similar to those used in melanoma, were not tolerable and had very high rates of TRAEs (49\%) and treatment-related deaths in the NSCLC population (39). This prompted reassessment of dose and schedule. The results of nivolumab $3 \mathrm{mg} / \mathrm{kg}$ every 2 weeks in combination with ipilimumab $1 \mathrm{mg} / \mathrm{kg}$ every 6 or 12 weeks in 77 previously untreated metastatic NSCLC patients have been recently published (40). The ORR was 38 and 47\% for the Q6 and Q12 week ipilimumab cohorts, respectively. In patients with PD-L1 expression of $1 \%$ or greater, the ORR was $57 \%$ for both cohorts. OS at 1 year in the ipilimumab Q6 week cohort was $69 \%$. The follow-up data were too immature at the time of publication to report the OS in the Q12 week cohort. Grade 3-4 TRAEs occurred in 33 and 37\% of patients in the Q6 and Q12 week cohorts, respectively. The majority of these TRAEs were auto-immune phenomena. No treatment-related deaths occurred. The results of the CheckMate 012 trial are the basis for the CheckMate 227 trial where PD-L1 positive (1\%) patients are randomized to nivolumab $3 \mathrm{mg} / \mathrm{kg}$ every 2 weeks with ipilimumab $1 \mathrm{mg} / \mathrm{kg}$ every 6 weeks versus nivolumab $3 \mathrm{mg} / \mathrm{kg}$ every 2 weeks versus platinum doublet. The PD-L1 negative patients are randomized to nivolumab with ipilimumab at the dose and schedule above versus nivolumab with platinumdoublet chemotherapy versus standard of care chemotherapy.

The phase Ib experience with the combination of durvalumab, an IgG1 antagonist antibody that binds PD-L1 and inhibits its function, with tremelimumab, a fully human IgG2 isotype that inhibits the CTLA-4 receptor, in NSCLC has recently been published (41). In this dose-finding study, 102 patients were enrolled; $94 \%$ of the patients had prior systemic therapy. The final tolerable dose was established as durvalumab $10 \mathrm{mg} / \mathrm{kg}$ and tremelimumab $1 \mathrm{mg} / \mathrm{kg}$ both given every 4 weeks. Serious TRAEs occurred in 37 (36\%) of 102 patients. Three treatment-related deaths occurred from suspected or confirmed autoimmunity (myasthenia gravis, pericardial effusion, and neuromuscular disorder). In the final cohort of 26 patients treated at the tremelimumab dose of $1 \mathrm{mg} / \mathrm{kg}$, patients with both PD-L1 high (25\%) as well as PD-L1 negative (0\%) tumors had ORR 22 and 40\%, respectively. Further work with this combination is being done in chemotherapy refractory (ARCTIC study) (42) and chemotherapy-naïve (MYSTIC study) (43) NSCLC patients.

\section{PD-L1 Expression}

Currently there are at least six monoclonal antibodies to assay PD-L1. The 28-8 antibody has been developed in conjunction with nivolumab. The 22C3 antibody has been developed with pembrolizumab. The 78-10 antibody has been developed with avelumab. Each of these three antibodies was developed initially on the DAKO autostainer platform. The SP142 antibody has been developed with atezolizumab. The SP263 antibody has been developed with durvalumab. Both of these antibodies were validated initially using the Ventana platform. Additional work has been published with the E1L3N antibody, which is commercially available and has been used in multiple laboratory-developed tests at numerous academic centers with both the DAKO and Ventana platforms. Work is now underway to cross compare the 
antibodies. Several studies have now been published including phase 1 of the BluePrint PD-L1 Assay Comparison Project (44). The results of this work consistently note that the 28-8, 22C3, and SP263 antibodies are comparable when staining tumor cells. The SP142 antibody has more variability when compared to the other three antibodies. In general, all four antibodies have greater variability when assaying ICs. Work is also underway to assess the reliability of some of the antibodies on alternative staining platforms. Recently, the Ventana platform has been shown to also be reliable for 22C3 analysis (45). While the FDA has approved many of these antibodies as either companion or complementary diagnostics, due to the high cost of these tests, globally, laboratorydeveloped assays for PD-L1 are likely to predominate. At this point, the authors recommend that a well-validated assay be used to determine the presence or absence of PD-L1 staining. The key to this is the requirement for rigorous validation methodology if a laboratory-developed assay is going to be used. This sentiment has been demonstrated in the recently presented Multi-center French Harmonization Project (46). The 22C3, 28-8, SP263, and E1L3N antibodies were generally comparable. This study did show significant variability in the detection of PDL1-positive tumor cells when laboratory-developed tests were used. The key is a thorough initial and ongoing validation process for laboratory-developed tests.

With that background, understanding the molecular determinants of response to immunotherapies is a difficult clinical challenge. Presently, PD-L1 expression levels have shown a variable ability to predict response to checkpoint inhibition. CheckMate 017 did not show any clear predictive benefit of PD-L1 analysis at the reported 1, 5, and 10\% cut points for squamous histology patients. CheckMate 057 did show significant improvement in ORR, PFS, and OS with nivolumab for non-squamous patients expressing any level of PD-L1, but there is clear escalating benefit with increasing PD-L1 expression in the published 1, 5, and 10\% cut points (47). The OAK study also showed that atezolizumab, when compared to docetaxel, produced OS benefit regardless of PD-L1 expression on either TC or IC, but again, increased magnitude of benefit is seen when patients with increasing PD-L1 expression are identified (33). The Keynote 010 trial only included PD-L1 positive patients, and although it does not offer information about the PD-L1-negative patients, there was increasing benefit when the patients with low expression (1-49\%) are contrasted with the patients with high expression $(\geq 50 \%)$ (31). Consistently in patients with non-squamous tumors who have progressed on platinum doublet, there is increased chance of benefit with increased PD-L1 expression. The struggle for clinicians is that the benefit in the PD-L1 low and/or negative groups is not zero, nor is it clinically insignificant, making use of PD-L1 as a biomarker in the refractory setting a challenge.

There has been documented success when stratifying patients for PD-L1 using the $22 \mathrm{C} 3$ antibody at the $50 \%$ cut point. This cut point was clinically validated during the Keynote 010 phase I trial that showed both pembrolizumab at either 2 or $10 \mathrm{mg} / \mathrm{kg}$ dose significantly improved OS in patients with $\geq 50 \%$ PD-L1 expression, which was numerically greater than the benefits seen in the low expressing cohort (48). Keynote 024 also demonstrated dramatic benefits of pembrolizumab in comparison to platinumdoublet chemotherapy in previously untreated patients with PD-L1 expression $\geq 50 \%$. This comes in contrast to what has been seen with the 28-8 antibody. The results of the CheckMate 026 trial are perplexing. If the $22 \mathrm{C} 3$ and $28-8$ antibodies select patients similarly, as is suggested by several recent publications including the initial publication of the BluePrint PD-L1 Assay Comparison Project, one would expect the patients treated with nivolumab who had $\geq 50 \%$ PD-L1 expression to do better with immunotherapy than chemotherapy, but this was not demonstrated $(44,49)$. The CheckMate 026 study was not designed nor powered to look at this subgroup. Confirmatory information about the benefits of PD-L1 inhibition in the chemotherapy-naïve first-line setting is needed. The Keynote 042 trial is ongoing (50). This trial is similar to the CheckMate 026 trial where patients with $\geq 1 \%$ PD-L1 staining are eligible to enroll. Patients are stratified by PD-L1 expression using the 50\% cut point and randomized to pembrolizumab versus standard platinum-doublet chemotherapy. The high expressing group can then be used to confirm the Keynote 024 data. As mentioned earlier, the ongoing Checkmate 227 trial has a nivolumab monotherapy arm for patients with $\geq 1 \%$ PD-L1 expression. Again, this trial was not designed to look specifically at the 50\% PD-L1-positive group but may yield a signal as to whether there is benefit of nivolumab alone in the first-line setting.

\section{Other Potential Biomarkers}

A multivariate exploratory analysis of baseline serum cytokines levels in 222 nivolumab-treated patients in either Checkmate 017 or 063 trials was presented at the April 2016 ELCC (51). The effect of the cytokine set on OS was quantified by generating an SQ-cytoscore defined as "high" or "low" based on the median cutoff. Those with a high SQ-cytoscore $(n=102)$ achieved an mOS of 15.6 months, approximately three times longer than 5.3 months of thosewithalowSQ-cytoscore $(n=120)$ (HR0.48,95\%CI0.36-0.64; $p<0.0001)$, respectively. While clinical factors are not suitable to determine sensitivity to PD-1 inhibition and PD-L1 expression does not predict response in squamous-NSCLC, the SQ-cytoscore may serve as a predictive marker for anti-PD-1 therapy. Prospective validation of these preliminary findings is required.

Due to tumor heterogeneity and the fluctuant infiltration of ICs into the tumor microenvironment (52), future biomarker investigations may look at other checkpoint molecules (53), TIIC (54), blood-based immune analyses (55), inflammatory gene signatures (56), and mutational load (57). In two independent cohorts, whole-exome sequencing of patients with NSCLC treated with pembrolizumab found an improved ORR, PFS, and durability in patients with higher tumor non-synonymous mutational load. Mutation burden was also associated with DNA repair pathway mutations, larger neoantigen burden, and molecular smoking signature; each factor was also correlated with clinical efficacy (57). Mutational burden is largely a consequence of chronic exposure to mutagens, and hence non-smoking NSCLC patients tend to harbor fewer mutations (58). Future prospective studies will need to explore the role of smoking exposure to durability of response. 


\section{Future Work}

Future trials will continue to explore the potential of combination therapy of PD-1 inhibition with chemotherapy, targeted therapy, or other immuno-oncology agents. Chemotherapy has been shown to increase PD-L1 expression on TCs $(59,60)$, in addition to possibly reducing the quantity and activity of suppressive ICs, inducing immunogenic cell death, activating and maturing dendritic cells, enhancing tumor antigen presentation, and increasing effector T-cell function (61). Beyond cytotoxic chemotherapy combinations, the PD-1 inhibitors are being combined with targeted therapies such as the EGFR and ALK inhibitors. As listed above, there are numerous clinical trials currently investigating the potential of combination immunotherapy in NSCLC, of which the majority are investigating the combination of PD-1/PD-L1 inhibition with CTLA-4 inhibition, but other novel checkpoint inhibitors are also entering phase I development. Studies are also investigating the role of PD-1 inhibition in the adjuvant setting in the ANVIL (nivolumab), PEARLS (pembrolizumab), IMpower010 (atezolizumab), and BR31 (durvalumab) trials as well as in locally advanced disease (PACIFIC). Beyond investigating immunotherapy in earlier stages of NSCLC, further work needs to be done to understand the mechanisms of resistance to this class of drugs. Loss-of-function mutations in the interferon-receptor-associated Janus kinase 1 (JAK1) and/ or Janus kinase 2 (JAK2) genes in melanoma and mismatch repair-deficient colon cancer have been implicated in acquired resistance, or possibly even primary resistance, to PD-1 inhibition $(62,63)$. JAK1/2 is required for signaling through the interferon- $\gamma$ receptor, a process required for TC PD-L1 expression (9). Hence inactivating JAK1/2 mutations lead to loss of PD-L1 expression and lack of response to anti-PD-1/ L1 therapy. While this mechanism has yet to be studied in NSCLC, it warrants further exploration as a possible biomarker of resistance. This paper also noted changes in the folding and localization of major histocompatibility complex (MHC) 1 to the cell surface in patients who have developed resistance to PD-1/L1 checkpoint inhibition through mutations in the beta2-microglobulin gene. The presence of MHC on the surface of tumor cells is required for T-cell cytotoxicity and lack of presence of MHC on the surface will mitigate the effect of PD-1/L1 checkpoint inhibition.

\section{REFERENCES}

1. Mahoney KM, Rennert PD, Freeman GJ. Combination cancer immunotherapy and new immunomodulatory targets. Nat Rev Drug Discov (2015) 14:561-84. doi:10.1038/nrd4591

2. Topalian SL, Hodi FS, Brahmer JR, Gettinger SN, Smith DC, McDermott DF, et al. Safety, activity, and immune correlates of anti-PD-1 antibody in cancer. N Engl J Med (2012) 366:2443-54. doi:10.1056/NEJMoa1200690

3. Hamid O, Robert C, Daud A, Hodi FS, Hwu WJ, Kefford R, et al. Safety and tumor responses with lambrolizumab (anti-PD-1) in melanoma. $N$ Engl J Med (2013) 369:134-44. doi:10.1056/NEJMoa1305133

4. EggermontAM, Chiarion-Sileni V, GrobJJ, DummerR, WolchokJD, SchmidtH, et al. Prolonged survival in stage III melanoma with ipilimumab adjuvant therapy. N Engl J Med (2016) 375:1845-55. doi:10.1056/NEJMoa1611299

5. Chen DS, Mellman I. Oncology meets immunology: the cancer-immunity cycle. Immunity (2013) 39:1-10. doi:10.1016/j.immuni.2013.07.012

\section{CONCLUSION}

Based on the data we have to date, in patients who have not received prior therapy for metastatic NSCLC, pembrolizumab could be offered as an alternative to platinum-doublet chemotherapy for those patients who express PD-L1 on $\geq 50 \%$ of their TCs based on the Keynote 024 trial. Confirmatory data will be forthcoming to support this single positive trial. In the refractory setting, nivolumab, pembrolizumab, and atezolizumab have all shown benefit in phase 3 clinical trials. Nivolumab is the only agent tested in a phase 3 trial with both known and unknown PD-L1 expression and demonstrated an OS benefit. Atezolizumab has shown a significant survival benefit in both the PD-L1 positive and negative patients (patients in this trial were required to have adequate tissue to document PD-L1 status). Pembrolizumab should only be given to patients who have known PD-L1 expression of at least $1 \%$. We look forward to further phase 3 randomized data of the immunotherapy combination strategies but for now this strategy should be reserved for clinical trials.

Anti-PD1 and PD-L1 in NSCLC treatment have durable response rates of approximately $20 \%$ that produce remarkable long-term survival. Toxicity is more favorable than chemotherapy, however, unique to immune checkpoint blockade are immune TREAs, of which the Grade 3-4 occurring in 5\% of patients leads to treatment discontinuation. PD-L1 expression levels show a variable response to checkpoint inhibition, and at present they are not essential to guide therapy in the patients who have failed platinum doublet. In contrast, PD-L1 expression appears to be critical in assessing the potential benefit of PD-1 inhibition in the chemotherapy-naive patient population. Determining predictive biomarkers to response is still undergoing further investigation. The rapidly evolving future of immunotherapy will continue with future studies investigating the potential of PD-1 inhibition in combination with chemotherapy, targeted therapy, or other immuno-oncology agents. We have entered a new era of lung cancer treatment.

\section{AUTHOR CONTRIBUTIONS}

RJ performed the search for new publications and proceedings relevant to this study; reviewed the paper prior to submission. MI drafted the paper.

6. Rudd CE, Taylor A, Schneider H. CD28 and CTLA-4 coreceptor expression and signal transduction. Immunol Rev (2009) 229:12-26. doi:10.1111/ j.1600-065X.2009.00770.x

7. Wang C, Thudium KB, Han M, Wang XT, Huang H, Feingersh D, et al. In vitro characterization of the anti-PD-1 antibody nivolumab, BMS-936558, and in vivo toxicology in non-human primates. Cancer Immunol Res (2014) 2:846-56. doi:10.1158/2326-6066.CIR-14-0040

8. Hodi FS, O'Day SJ, McDermott DF, Weber RW, Sosman JA, Haanen JB, et al. Improved survival with ipilimumab in patients with metastatic melanoma. N Engl J Med (2010) 363:711-23. doi:10.1056/NEJMoa1003466

9. Pardoll DM. The blockade of immune checkpoints in cancer immunotherapy. Nat Rev Cancer (2012) 12:252-64. doi:10.1038/nrc3239

10. Data from: Global Cancer Facts and Figures. 3rd ed. American Cancer Society (2012). Available from: https://www.cancer.org/content/dam/cancer-org/ research/cancer-facts-and-statistics/global-cancer-facts-and-figures/globalcancer-facts-and-figures-3rd-edition.pdf 
11. Herbst RS, Heymach JV, Lippman SM. Lung cancer. N Engl J Med (2008) 359:1367-80. doi:10.1056/NEJMra0802714

12. NSCLC Meta-Analyses Collaborative Group. Chemotherapy in addition to supportive care improves survival in advanced non-small-cell lung cancer: a systematic review and meta-analysis of individual patient data from 16 randomized controlled trials. JClin Oncol (2008) 26:4617-25. doi:10.1200/ JCO.2008.17.7162

13. Travis WD. Pathology of lung cancer. Clin Chest Med (2011) 32:669-92. doi:10.1016/j.ccm.2011.08.005

14. Groome PA, Bolejack V, Crowley JJ, Kennedy C, Krasnik M, Sobin LH, et al. The IASLC Lung Cancer Staging Project: validation of the proposals for revision of the $\mathrm{T}, \mathrm{N}$, and $\mathrm{M}$ descriptors and consequent stage groupings in the forthcoming (seventh) edition of the TNM classification of malignant tumours. J Thorac Oncol (2007) 2:694-705. doi:10.1097/JTO.0b013e31812d05d5

15. Goldstraw P, Crowley J, Chansky K, Giroux DJ, Groome PA, Rami-Porta R, et al. The IASLC Lung Cancer Staging Project: proposals for the revision of the TNM stage groupings in the forthcoming (seventh) edition of the TNM Classification of malignant tumours. JThorac Oncol (2007) 2:706-14. doi:10.1097/JTO.0b013e31812f3cla

16. Mok TS, Wu YL, Thongprasert S, Yang CH, Chu DT, Saijo N, et al. Gefitinib or carboplatin-paclitaxel in pulmonary adenocarcinoma. N Engl J Med (2009) 361:947-57. doi:10.1056/NEJMoa0810699

17. Shaw AT, Kim DW, Nakagawa K, Seto T, Crino L, Ahn MJ, et al. Crizotinib versus chemotherapy in advanced ALK-positive lung cancer. $N$ Engl J Med (2013) 368:2385-94. doi:10.1056/NEJMoa1214886

18. Shaw AT, Engelman JA. Ceritinib in ALK-rearranged non-small-cell lung cancer. N Engl J Med (2014) 370:2537-9. doi:10.1056/NEJMc1404894

19. Janne PA, Yang JC, Kim DW, Planchard D, Ohe Y, Ramalingam SS, et al. AZD9291 in EGFR inhibitor-resistant non-small-cell lung cancer. N Engl J Med (2015) 372:1689-99. doi:10.1056/NEJMoa1411817

20. Sequist LV, Soria JC, Goldman JW, Wakelee HA, Gadgeel SM, Varga A, et al. Rociletinib in EGFR-mutated non-small-cell lung cancer. N Engl J Med (2015) 372:1700-9. doi:10.1056/NEJMoa1413654

21. Camidge DR, Pao W, Sequist LV. Acquired resistance to TKIs in solid tumours: learning from lung cancer. Nat Rev Clin Oncol (2014) 11:473-81. doi:10.1038/ nrclinonc.2014.104

22. Melosky B, Chu Q, Juergens R, Leighl N, McLeod D, Hirsh V. Pointed progress in second-line advanced non-small-cell lung cancer: the rapidly evolving field of checkpoint inhibition. J Clin Oncol (2016) 34:1676-88. doi:10.1200/ JCO.2015.63.8049

23. Rizvi NA, Mazieres J, Planchard D, Stinchcombe TE, Dy GK, Antonia SJ, et al. Activity and safety of nivolumab, an anti-PD-1 immune checkpoint inhibitor, for patients with advanced, refractory squamous non-small-cell lung cancer (CheckMate 063): a phase 2, single-arm trial. Lancet Oncol (2015) 16:257-65. doi:10.1016/S1470-2045(15)70054-9

24. Ahn MJ, Yang J, Yu H, Saka H, Ramalingam S, Goto K, et al. 136O: osimertinib combined with durvalumab in EGFR-mutant non-small cell lung cancer: results from the TATTON phase Ib trial. J Thorac Oncol (2016) 11:S115. doi:10.1016/S1556-0864(16)30246-5

25. Nishio M, Hida T, Nakagawa K, Sakai H, Nogami N, Atagi S, et al. Phase II studies of nivolumab (anti-PD-1, BMS-936558, ONO-4538) in patients with advanced squamous (sq) or nonsquamous (non-sq) non-small cell lung cancer (NSCLC). J Clin Oncol (2015) 33:abstr 8027.

26. Scartozzi M, Mazzanti P, Giampieri R, Berardi R, Galizia E, Gasparini S, et al. Clinical predictive factors for advanced non-small cell lung cancer (NSCLC) patients receiving third-line therapy: selecting the unselectable? Lung Cancer (2010) 68:433-7. doi:10.1016/j.lungcan.2009.07.008

27. Brahmer J, Reckamp KL, Baas P, Crino L, Eberhardt WE, Poddubskaya E, et al. Nivolumab versus docetaxel in advanced squamous-cell non-smallcell lung cancer. N Engl J Med (2015) 373:123-35. doi:10.1056/NEJMoa1504627

28. Borghaei H, Brahmer JR, Horn L, Ready N, Steins M, Felip E, et al. Nivolumab (nivo) vs docetaxel (doc) in patients (pts) with advanced NSCLC: CheckMate 017/057 2-y update and exploratory cytokine profile analyses. J Clin Oncol (2016) 34:abstr 9025.

29. Borghaei H, Paz-Ares L, Horn L, Spigel DR, Steins M, Ready NE, et al. Nivolumab versus docetaxel in advanced nonsquamous non-small-cell lung cancer. N Engl J Med (2015) 373:1627-39. doi:10.1056/NEJMoa1507643
30. Herbst RS, Baas P, Kim DW, Felip E, Perez-Gracia JL, Han JY, et al. Pembrolizumab versus docetaxel for previously treated, PD-L1-positive, advanced non-small-cell lung cancer (KEYNOTE-010): a randomised controlled trial. Lancet (2016) 387:1540-50. doi:10.1016/S0140-6736(15)01281-7

31. Garon EB, Herbst RS, Kim D, Felip E, Perez-Gracia JL, Han J, et al. Pembrolizumab vs docetaxel for previously treated advanced NSCLC with a PD-L1 tumor proportion score (TPS) 1\%-49\%: results from KEYNOTE-010. J Clin Oncol (2016) 34:abstr 9024.

32. Rittmeyer A, Barlesi F, Waterkamp D, Park K, Ciardiello F, von Pawel J, et al. Atezolizumab versus docetaxel in patients with previously treated nonsmall-cell lung cancer (OAK): a phase 3, open-label, multicentre randomised controlled trial. Lancet (2016) 389:255-65. doi:10.1016/S0140-6736(16) 32517-X

33. Barlesi F, Park K, Ciardiello F, Pawel JV, Gadgeel S, Hida T, et al. Primary analysis from $\mathrm{OAK}$, a randomized phase III study comparing atezolizumab with docetaxel in 2L/3L NSCLC. Ann Oncol (2016) 27:LBA44_R. doi:10.1093/ annonc/mdw435.43

34. Reck M, Rodriguez-Abreu D, Robinson AG, Hui R, Csoszi T, Fulop A, et al. Pembrolizumab versus chemotherapy for PD-L1-positive nonsmall-cell lung cancer. N Engl J Med (2016) 375:1823-33. doi:10.1056/ NEJMoa1606774

35. Socinski M, Creelan B, Horn L, Reck M, Paz-Ares L, Steins M, et al. NSCLC, metastatic CheckMate 026: a phase 3 trial of nivolumab vs investigator's choice (IC) of platinum-based doublet chemotherapy (PT-DC) as first-line therapy for stage iv/recurrent programmed death ligand 1 (PD-L1)-positive NSCLC. Ann Oncol (2016) 27:LBA7_R. doi:10.1093/annonc/mdw435.39

36. Rizvi NA, Hellmann MD, Brahmer JR, Juergens RA, Borghaei H, Gettinger S, et al. Nivolumab in combination with platinum-based doublet chemotherapy for first-line treatment of advanced non-small-cell lung cancer. J Clin Oncol (2016) 34:2969-79. doi:10.1200/JCO.2016.66.9861

37. Langer CJ, Gadgeel SM, Borghaei H, Papadimitrakopoulou VA, Patnaik A, Powell SF, et al. Carboplatin and pemetrexed with or without pembrolizumab for advanced, non-squamous non-small-cell lung cancer: a randomised, phase 2 cohort of the open-label KEYNOTE-021 study. Lancet Oncol (2016) 17: 1497-508. doi:10.1016/S1470-2045(16)30498-3

38. Patnaik A, Socinski MA, Gubens MA, Gandhi L, Stevenson J, Bachman RD, et al. Phase 1 study of pembrolizumab (pembro; MK-3475) plus ipilimumab (IPI) as second-line therapy for advanced non-small cell lung cancer (NSCLC): KEYNOTE-021 cohort D. J Clin Oncol (2015) 33:abstr 8011.

39. Antonia SJ, Gettinger SN, Chow LQM, Juergens RA, Borghaei H, Shen Y, et al. Nivolumab (anti-PD-1; BMS-936558, ONO-4538) and ipilimumab in first-line NSCLC: interim phase I results. J Clin Oncol (2014) 32:abstr 8023.

40. Hellmann MD, Rizvi NA, Goldman JW, Gettinger SN, Borghaei H, Brahmer JR, et al. Nivolumab plus ipilimumab as first-line treatment for advanced nonsmall-cell lung cancer (CheckMate 012): results of an open-label, phase 1, multicohort study. Lancet Oncol (2017) 18:31-41. doi:10.1016/S1470-2045 (16)30624-6

41. Antonia S, Goldberg SB, Balmanoukian A, Chaft JE, Sanborn RE, Gupta A, et al. Safety and antitumour activity of durvalumab plus tremelimumab in non-small cell lung cancer: a multicentre, phase $1 \mathrm{~b}$ study. Lancet Oncol (2016) 17:299-308. doi:10.1016/S1470-2045(15)00544-6

42. Planchard D, Yokoi T, McCleod MJ, Fischer JR, Kim YC, Ballas M, et al. A phase III study of durvalumab (medi4736) with or without tremelimumab for previously treated patients with advanced NSCLC: rationale and protocol design of the ARCTIC study. Clin Lung Cancer (2016) 17:232-6. doi:10.1016/j. cllc.2016.03.003

43. Peters S, Antonia S, Goldberg SB, Heymach JV, Kim ES, Nakagawa K, et al. 191TiP: MYSTIC: a global, phase 3 study of durvalumab (MEDI4736) plus tremelimumab combination therapy or durvalumab monotherapy versus platinum-based chemotherapy (CT) in the first-line treatment of patients (pts) with advanced stage IV NSCLC. J Thorac Oncol (2016) 11:S139-40. doi:10.1016/S1556-0864(16)30300-8

44. Hirsch FR, McElhinny A, Stanforth D, Ranger-Moore J, Jansson M, Kulangara K, et al. PD-L1 immunohistochemistry assays for lung cancer: results from phase 1 of the blueprint PD-L1 IHC assay comparison project. J Thorac Oncol (2017) 12:208-22. doi:10.1016/j.jtho.2016.11.2228

45. Neuman T, London M, Kania-Almog J, Litvin A, Zohar Y, Fridel L, et al. A harmonization study for the use of 22C3 PD-L1 immunohistochemical 
staining on Ventana's platform. J Thorac Oncol (2016) 11:1863-8. doi:10.1016/j. jtho.2016.08.146

46. Adam J, Rouquette I, Damotte D, Badoual C, Danel C, Damiola F, et al. PL04a.04: multicentric french harmonization study for PD-L1 IHC testing in NSCLC. J Thorac Oncol (2017) 12:S11-2. doi:10.1016/j.jtho.2016.11.013

47. Paz-Ares L, Horn L, Borghaei H, Spigel DR, Steins M, Ready N, et al. Phase III, randomized trial (CheckMate 057) of nivolumab (NIVO) versus docetaxel (DOC) in advanced non-squamous cell (non-SQ) non-small cell lung cancer (NSCLC). JClin Oncol (2015) 33:abstr LBA109. doi:10.1200/ jco.2015.33.18_suppl.lba109

48. Garon EB, Rizvi NA, Hui R, Leighl N, Balmanoukian AS, Eder JP, et al. Pembrolizumab for the treatment of non-small-cell lung cancer. N Engl J Med (2015) 372:2018-28. doi:10.1056/NEJMoa1501824

49. Ratcliffe MJ, Sharpe A, Midha A, Barker C, Scott M, Scorer P, et al. Agreement between programmed cell death ligand-1 diagnostic assays across multiple protein expression cut-offs in non-small cell lung cancer. Clin Cancer Res (2017) 10. doi:10.1158/1078-0432.CCR-16-2375

50. De Lima Lopes G, Wu YL, Sadowski S, Zhang J, Rangwala R, Kush D, et al. P2.43: pembrolizumab vs platinum-based chemotherapy for PD-L1+ NSCLC: phase 3, randomized, open-label KEYNOTE-042 (NCT02220894): track: immunotherapy. J Thorac Oncol (2016) 11:S244-5. doi:10.1016/j.jtho. 2016.08.114

51. Ramalingam S, Lena H, Rizvi NA, Wolf J, Cappuzzo F, Zalcman G, et al. Nivolumab in patients (pts) with advanced refractory squamous (SQ) non-small cell lung cancer (NSCLC): 2-year follow-up from CheckMate 063 and exploratory cytokine profiling analyses. J Thorac Oncol (2016) 11: S57-166.

52. McLaughlin J, Han G, Schalper KA, Carvajal-Hausdorf D, Pelekanou V, Rehman J, et al. Quantitative assessment of the heterogeneity of PD-L1 expression in non-small-cell lung cancer. JAMA Oncol (2016) 2:46-54. doi:10.1001/ jamaoncol.2015.3638

53. Dong H, Zhu G, Tamada K, Chen L. B7-H1, a third member of the B7 family, co-stimulates T-cell proliferation and interleukin-10 secretion. Nat Med (1999) 5:1365-9. doi:10.1038/70932

54. Schalper KA, Velcheti V, Carvajal D, Wimberly H, Brown J, Pusztai L, et al. In situ tumor PD-L1 mRNA expression is associated with increased TILs and better outcome in breast carcinomas. Clin Cancer Res (2014) 20:2773-82. doi:10.1158/1078-0432.CCR-13-2702

55. Herbst RS, Soria JC, Kowanetz M, Fine GD, Hamid O, Gordon MS, et al. Predictive correlates of response to the anti-PD-L1 antibody MPDL3280A in cancer patients. Nature (2014) 515:563-7. doi:10.1038/nature14011
56. Ascierto PA, Capone M, Urba WJ, Bifulco CB, Botti G, Lugli A, et al. The additional facet of immunoscore: immunoprofiling as a possible predictive tool for cancer treatment. J Transl Med (2013) 11:54. doi:10.1186/14795876-11-54

57. Rizvi NA, Hellmann MD, Snyder A, Kvistborg P, Makarov V, Havel JJ, et al. Cancer immunology. Mutational landscape determines sensitivity to PD-1 blockade in non-small cell lung cancer. Science (2015) 348:124-8. doi:10.1126/ science.aaa1348

58. Govindan R, Ding L, Griffith M, Subramanian J, Dees ND, Kanchi KL, et al. Genomic landscape of non-small cell lung cancer in smokers and neversmokers. Cell (2012) 150:1121-34. doi:10.1016/j.cell.2012.08.024

59. Peng J, Hamanishi J, Matsumura N, Abiko K, Murat K, Baba T, et al. Chemotherapy induces programmed cell death-ligand 1 overexpression via the nuclear factor-kappaB to foster an immunosuppressive tumor microenvironment in ovarian cancer. Cancer Res (2015) 75:5034-45. doi:10.1158/ 0008-5472.CAN-14-3098

60. Zhang P, Ma Y, Lv C, Huang M, Li M, Dong B, et al. The up-regulation of PD-L1 promotes the resistant response in non-small cell lung cancer patients with neo-adjuvant chemotherapy. Cancer Sci (2016) 107:1563-71. doi:10.1111/ cas. 13072

61. Apetoh L, Ladoire S, Coukos G, Ghiringhelli F. Combining immunotherapy and anticancer agents: the right path to achieve cancer cure? Ann Oncol (2015) 26:1813-23. doi:10.1093/annonc/mdv209

62. Shin DS, Zaretsky JM, Escuin-Ordinas H, Garcia-Diaz A, Hu-Lieskovan S, Kalbasi A, et al. Primary resistance to PD-1 blockade mediated by JAK1/2 mutations. CancerDiscov (2017) 7:188-201. doi:10.1158/2159-8290.CD-16-1223

63. Zaretsky JM, Garcia-Diaz A, Shin DS, Escuin-Ordinas H, Hugo W, Hu-Lieskovan S, et al. Mutations associated with acquired resistance to PD-1 blockade in melanoma. N Engl J Med (2016) 375:819-29. doi:10.1056/ NEJMoa1604958

Conflict of Interest Statement: RJ: Consulting/Advisory Boards for BMS, Merck, AstraZeneca, Pfizer, Roche as well as honoraria from each of them. MI declares no conflict of interest.

Copyright $\odot 2017$ Iafolla and Juergens. This is an open-access article distributed under the terms of the Creative Commons Attribution License (CC BY). The use, distribution or reproduction in other forums is permitted, provided the original author(s) or licensor are credited and that the original publication in this journal is cited, in accordance with accepted academic practice. No use, distribution or reproduction is permitted which does not comply with these terms. 